\title{
A Critical Analysis of Ethiopian Civil Code Governing Sale of Goods in the Light of International Convention and Principles
}

\author{
Mamenie Endale Messelu \\ School of Law, Arba Minch University, Arba Minch, Ethiopia \\ Email: mamenieendale@gmail.com
}

Received 11 May 2016; accepted 17 June 2016; published 20 June 2016

Copyright (C) 2016 by author and Scientific Research Publishing Inc.

This work is licensed under the Creative Commons Attribution-NonCommercial International License (CC BY-NC). http://creativecommons.org/licenses/by-nc/4.0/ (c) (i) (2) Open Access

\begin{abstract}
This paper critically analyzes the 1960 Ethiopian civil code governing sales of goods in the context of international convention and principles. And, the paper argues that the Ethiopian civil code governing sale of goods is no compatible with the main provisions of the international convention and principles. In order to examine and prove this hypothesis, particular attention was directed towards examining the main provisions of the international convention and principles i.e. CISG, UPICC, PECL and UCC and related this to critically analyze the Ethiopian civil code governing sale of goods. This enables for the researcher to analyze and establish whether the Ethiopian civil code governing sale of goods is compatible with the international convention and principles. By doing so, the paper will help: 1) the potential contracting parties to choice the best and suitable governing law's or provisions of a given law; and 2) the Ethiopian government to understand which international convention and principles should be adopted by a country and in which provisions of a given law should the government put its reservation. From the comparisons, the researcher found that the Ethiopian civil code governing sales of goods are incompatible with the aforementioned international convention and principles on the areas of scope of applicability, interpretation, formation of the contract, obligation of the parties, risk of loss, breach of contract and remedies. Therefore, we can understand that, one body of law is not a perfect body of law, and neither can it be, and to some extent they enable themselves to supplement each other and fit well with each other, rather than compete or claim to displace the other.
\end{abstract}

\section{Keywords}

Goods, Civil Code, CISG, UPICC, PECL, UCC 


\section{Introduction}

In the present day of unprecedented trade liberalization at bilateral, regional and multilateral level accompanied by the exponential development of new information technologies has changed the way traders interact with one another i.e. international business transactions are highly increasing ${ }^{1}$ (WTO, 2015). Due to this reason, the regulation of international commerce through the national laws is a barrier to the promotion of international trade and also it is considered to be a threat to the sovereignty of a country (Fernando, 2015).

It seems by realizing of this barrier that different attempts are made to harmonize the governing laws in sales of goods at international level. For example, there was a move towards the codification of the United Nations Convention on Contracts for the International Sale of Goods (here in after called CISG); the UNIDROIT Principles of International Commercial Contracts (here in after called UNIDROIT Principles or UPICC); the Principles of European contract law (here in after called PECL); and the Uniform commercial code (here in after called UCC).

There are a lot of ample opportunities for the Ethiopian trader to access the world market. ${ }^{2}$ And, their involvement in the world market may invite the application of CISG, UPICC, PECL and UCC.

However, Ethiopia neither updated its civil code governing sale of goods nor accepted any international convention and principles to regulate international sale of goods. Due to this reason, this paper argues that the Ethiopian civil code governing sale of goods is no compatible with the main provisions of the international convention and principles. In order to examine and prove this hypothesis, particular attention will be directed towards examining the main provisions of the CISG, UPICC, PECL and UCC and related this to critically analyze the Ethiopian civil code governing sale of goods. This enables the researcher to analyze and establish whether the Ethiopian civil code governing sale of goods is compatible with the international convention and principles.

By doing so, the paper serves four purposes; it helps: 1) the academician to understand whether the Ethiopian civil code governing sale of goods is compatible with the international convention and principles; 2) the revision committee of the civil code to update the Ethiopian civil code and/or to draft a comprehensive code governing international sale of goods; and 3) the potential contracting parties to choice the best and suitable governing law's or provisions of a given law; and 4) the Ethiopian government to understand which international convention and principles should be adopted by a country and in which provisions of a given law should the government put its reservation.

\section{General Overview of the Study Instruments and Their Applicability in Ethiopia}

\subsection{General Overview of the Study Instruments}

\subsubsection{The Recognition of Sales of Goods under the Ethiopian Civil Code}

The Ethiopian law of contracts is found mainly in the Civil Code. It consists of 3367 articles, divided into five books and twenty-two titles: Book I: Persons; Book II: Family and Successions; Book III: Goods; Book IV: Obligations; Book V: Special Contracts. The sale of goods is governed by Book V (in the Title XV) (Civil Code of Ethiopia, 1960). Besides, Art. 1676(1) of the civil code provides that "the general provisions of this Title (Book IV, Title XII on contracts in general) shall apply to contracts regardless of the nature thereof and the parties thereto" and "nothing in this Title shall affect such special provisions applicable to certain contracts as are laid down in Book V of this Code and in the Commercial Code". Moreover, Article 1677 provides "the relevant provisions of this Title (Book IV, Title XII on contracts in general) apply to obligations notwithstanding that they do not arise out of a contract" and "nothing in this Title affect the special provisions applicable to certain obliga-

${ }^{1}$ WTO, International Trade Statistics of 2015, available at https://www.wto.org/english/res_e/statis_e/its2015_e/its2015_e.pdf. The average share of exports and imports of goods and commercial services in world GDP increased significantly from 20 per cent in 1995 to 30 per cent in 2014 (in value terms). In other words, today's GDP is highly influenced by international trade. World merchandise exports (excluding significant re-exports from Hong Kong, China) have experienced strong growth over the last 20 years, climbing to US \$18,494 billion in 2014, almost four times the value of US \$5018 billion recorded in 1995. In 1995, the total value of world exports to developing countries was US \$487 billion. By 2014, it had risen to US \$4198, nearly nine times as high. South-South trade (i.e. exports from developing economies to other developing economies) has increased steadily since 2000, reaching 52 per cent of developing countries' total merchandise exports in 2014 compared with 38 per cent in 1995.

${ }^{2}$ The Ethiopian trader can access: the African market via COMMESA; Europe, Africa, Caribbean, and pacific countries market via Economic Partnership Agreement (EPA) of cotonou Agreement; preferential market access to EU under Everything But Arms (EBA); US market via AGOA (African Growth and Opportunity Act) but it is path out in 2015 unless re-negotiated; Australia, Canada, Japan, Norway, Sweden, USA and most countries of Europe market via GSP (Generalized System of Preference); China allows almost all Ethiopian Export products (Agricultural products and raw materials) duty free access; and Ethiopia’s geographical proximate to the middle East and Gulf countries offers great potential market access for the Ethiopian trader. 
tions by reason of their origin or nature”. Therefore, whenever one is faced with a certain dispute involving sale of goods, one has to first see whether there are relevant provisions under Book V (in the Title XV). And it is only failing this that one can resort to the general provisions of Title XII on contracts in general.

\subsubsection{The United Nations Convention on Contracts for International Sale of Goods (CISG)}

CISG adopted by the UN in 1980, the CISG establishes a comprehensive code of legal norms in the international sale of goods. It has four parts and 101 Articles on sphere of application and general provisions; on formation of contracts; on sale of goods and on final provisions ${ }^{3}$ (CISG, 1980). According to its Preamble, the CISG's objectives are: Promotion of the establishment of a new international economic order; Development of international trade on the basis of equality and mutual benefit; and the removal of legal barriers in international trade. The CISG only applies to contracts of sale of goods between parties whose places of business are in different states and supplies gap-filling rules. The CISG provides an equitable and modern framework for the contract of sale, which is the backbone of international trade in all countries. In short, it only applies to international commercial sale of goods.

\subsubsection{The UNIDROIT Principle of International Commercial Contracts 2010 (UPICC)}

The latest principle on International Commercial Contracts (2010) adopted by the International Institute for the Unification of Private Law has eleven Chapters ${ }^{4}$ (UPICC, 2010). In relation to its purpose and condition of applicability, its Preamble stated that the principle: Sets forth general rules for international commercial contracts that are applicable when the parties have: 1) agreed that their contract be governed by them, 2) agreed that their contract be governed by general principles of law, the lexmercatoria or the like, 3) not chosen any law to govern their contract, these rules may be used to interpret or supplement international: a) uniform law instruments and b) domestic law; and finally the principle may serve as a model for national and international legislators. Both the CISG and UPICC enable to the international community to harmonize and modernize international contract law (Bonell, 2002).

\subsubsection{The Principles of European Contract Law 2002 (PECL)}

Adopted by the European Union on the recommendation of the Lando Commission, its contents are very close to UNIDROIT Principles (Bonell, 1994). It has seventeen chapters ${ }^{5}$. The condition of application of the PECL (Art. 1) are more or less similar with that of the UPICC. However, Unlike the UNIDROIT Principles as well as the CISG which applies exclusively to international contracts, the Principles of European contract law are to be applicable 1) to domestic European contracts as well as to trans-European Union international contracts and 2) to virtually all European contracts, including merchant consumer contracts as well as contracts between commercial parties.

\subsubsection{The Uniform Commercial Code (UCC)}

Developed mainly by the American Law Institute (ALI), the Uniform Commercial Code (the UCC) is now adopted by all but one state (Louisiana) in the U.S.A. It is a comprehensive model law on the important areas of commercial law and has nine Articles $^{6}$ (UCC, 1952).

\subsection{The Application of CISG, UPICC, PECL, and UCC in Ethiopia}

Even though Ethiopia does not have codified private international rules, general observation can be made about the possible principles and rules that would help courts determine the applicable law based on some of the findings of scholars on the subject and the new draft proclamation on private international law (Kebede \& Kassim, 2009). There are circumstances where the Ethiopian civil code, CISG, UPICC, PECL and UCC are applied in an international contract of sale in which an Ethiopian national is a party. The application of those documents in Ethiopia with respect to international contract is based on three grounds: 1) freedom of contract, 2) rules of pri-

${ }^{3}$ U.N. Convention on Contracts for the International Sale of Goods, Apr. 11, 1980, S. Treaty Doc. No. 98-9 (1983), 1489 U.N.T.S, http://www.uncitral.org/pdf/english/clout/CISG-digest-2012e.pdf; http://www.cisgac.com/default.php?sid=128.

${ }^{4}$ UNIDROIT Principles of International Commercial Contracts (2010). http://www.uncitral.org/uncitral/en/index.htm.

${ }^{5}$ See Principle of European Law (2002), http://www.trans-lex.org; accessed on February6, 2016.

${ }^{6}$ Uniform Commercial Code, Vol. 10 (2007). For further information about its structural layout visit the South Dakota legislature website sdlegislature.gov/statutes/Display S... last visited on February 6, 2016. 
vate international law, and 3) lexmercatoria. Accordingly, Firstly, the courts will have to see if the parties to any international contract have made effective choice of the applicable law. As sale contract is of law where freedom of the parties is given higher value than any other area of law, the appropriate system of law to govern the formation and effects of contracts containing foreign element in principle is left for the parties to choose. And, the contracting parties may choose either one or more of the above legal instruments. For example, if a company with its place of business in Ethiopia sells to one with its place of business in the People's Republic of China (PRC), these international instruments applies when both the contracting parties choose it as a governing law. Besides, If, a company with its place of business in Ethiopia enters into a contract of sale with an Indonesian company (Indonesia is not a Contracting State as May 2016), the CISG can apply through the choose of the parties. Just as CISG can be applied when it is chosen by the contracting parties in Ethiopia, UPICC, PECL \& UCC can also be applied (Tesfaye \& Fetewi, 2009). However, the parties are not free to choose any law they like. They have to have substantial relationship with the parties and the chosen law should not be contrary to the public policy of the forum (FDRE Ministry of Justice and Legal System Research Institute, 2004).

In the absence of effective choice by the parties, the following options may be forwarded: 1) LEX LOCI CONTRACTUS i.e. the law of the place where the contract is concluded; 2) LEX LOCI SOLUTIONS i.e. the law of the place the contract is performed; 3 ) the law of the state with which the contract has substantial connection or otherwise termed as the "proper law of the contract" (Tesfaye \& Fetewi, 2009). But, it should be born in mind that not all the matters affecting the contract are governed by one system of law. It is possible that different particular aspects of the contract could be governed by different laws. For instance, CISG, UPICC, PECL, UCC and the civil code provisions may govern different aspects of a single contract.

By applying the rules of private international law, if the applicable law is the law of the contracting state, the CISG will be applicable subject to the fulfillment of its pre-condition (Tesfaye \& Fetewi, 2009). e.g. if French and Ethiopian parties choose French law as the law of the contract, the CISG would normally apply because France is a contracting state notwithstanding the fact that Ethiopia is not a contracting state. In cases where CISG is applied by the Ethiopian courts, UPICC \& PECL can also be used in order to supplement the CISG. Besides, they may choose via an expression of lexmercatoria by an arbitral tribunals in Ethiopia (Tesfaye \& Fetewi, 2009). Finally, as per Art. 1713 of the Ethiopian civil code, the contracting parties are bound not only by express terms of their contract but also by such incidental effects as may be attached to it considering trade usage, custom, and good faith i.e. CISG, UPICC, PECL, \& UCC can be referred to.

\section{Critical Comparison of the Ethiopian Civil Code and International Instruments}

\subsection{Purpose, Feature and Scope of Applicability}

The functions of the civil code governing sale of goods are: facilitating transaction, regulating market, filling contractual gaps, encouraging optimal cooperation and performance. In addition to this function provided under the civil code, the CISG, UPICC, PECL \& UCC are designed among other things to facilitate and promote international trade by making uniform laws, which result in legal certainty and predictability.

In relation to their feature, unlike the civil code \& CISG which are considered as hard laws because of they represent a legally binding enforceable regulations, the UPICC and PECL are considered as soft laws because they merely suggest the goals that have to be achieved.

In relation to their scope of applicability, the UPICC does not apply to domestic contracts rather it is intended to operate globally, which are broader in scope and more detailed in provisions than the CISG (Bonell, 2002). Similarly, while the Ethiopian civil code, UCC \& PECL are of a narrower geographic focus than CISG \& UPICC, they covers a wider area of law. The PECL is applicable to contracts entered into by parties who belong to Member States of the European Union whereas the UPICC and the CISG are applicable universally. The civil code too apply to domestic contracts unless the parties choose for its international applicability. UCC is also applicable for contracts of sale of goods made between two or more traders of US state except Louisiana or for international contract via choices of contracting party.

\subsection{Formation of a Contract}

The international contract of sale of goods is mostly concluded via the exchange of offer and acceptance. In respect to offer and acceptance, the section of the civil code which governs contract of sale of goods is silent. So, as per Art. 1676(1) of the CC, the general contract provisions of offer and acceptance will apply for the contract 
of sale of goods. In relation to the formation of a contract the following are the basis of comparison.

\subsubsection{Silence Not Amount to Acceptance}

The European principles of contract law under section 2, Art. 2:204(2), specifies that silence or inactivity does not in itself amounts to acceptance. This principles of contract also incorporated under Art. 18(1) of CISG, under Art. 2.1.6 (1) of the UNIDROIT principles of commercial and under Art. 1682 of civil code of Ethiopia.

However, even though all the above legal instruments incorporate the principle that silence does not amount to acceptance in black and white term, the Ethiopian civil code includes a little bit different thing in this regard. Unlike the above international commercial instruments, the Ethiopian civil code incorporates exceptional grounds that make silent will amount to acceptance. Silence may amounts to acceptance if; 1) there is pre-existing business relations or clear contractual relation has already been established, which enables to believe that the parties are aware of the extent of the obligations, 2) where the proposal is for making a subsidiary or complementary contract to the original contract, and the offer is made in a special document; and 3) an offer is made to persons who are required by law or by the terms of a concession granted to them by the government to conclude certain contracts on terms stipulated in advance like supply of electricity and telecom service here in Ethiopia.

But we cannot find such kinds of exceptional grounds that show the possibility of silence may amount to acceptance in international instruments like CSIG, PECL and UPICC. Therefore, it is possible to say that the Ethiopian civil code is unique in this regard.

\subsubsection{The Formality Requirement}

The civil code (Art. 1719), CISG (Art. 11), UPICC (Art. 1.2), and PECL (Art. 1:102) make clear that contracts need not be in writing to be enforceable. This is in contrast to UCC (\$2-201), which requires contracts for the sale of goods in excess of $\$ 500$ to be in writing. Besides, under the UPICC (Art. 3.1.2) a contract can be modified or terminated by the parties in any form. This is contrary to the provisions of the civil code (Art. 1722), CISG (Art. 29(2) \& PECL (Art. 2:106)), which states that a written contract shall be modified only in writing. Whereas, the UPICC, PECL \& UCC take consensualism has an effect on both the formal existence of contracts as well as their substance, the CISG limits the relevance of consensualism to question of the form of legal acts ${ }^{7}$ (Marell, 2016). Here, the civil code follows the approach of UPICC and PECL.

\subsubsection{Modified Acceptance}

The UCC (§2:206(3)) stated that only the terms that both parties have agreed to will be included in the contract. On the other hand, the civil code, CISG, UPICC and PECL provide that a contract is formed only when the "meeting of minds" occurs. Accordingly, if the additional terms do not materially alter the facts of the offer, then a contract is formed; if they do, there is no "meeting of the minds" and no valid contract (see Art. 2:208 PECL, Art. 2.1.11 UPICC, Art. 19(1) CISG). But, under the civil code (Art. 1694), even the modification which has not materially alter the terms of a contract as long as it does not conform the terms of the offer is considered as a rejection of offer.

\subsubsection{Making a Proposal to the Public}

Whereas the PECL (Art. 2:201(2)) stated that making a proposal to the public can constitute as an offer, the CISG (Art. 14) and the civil code (Art. 1689) treat it as an invitation to offer. The UPICC seems to take the middle approach depending on the clarity and the exhaustiveness of content of the proposal (Guillemard, 2000/2001).

\subsubsection{Revocation of Offer}

Under the CISG (Art. 16(2)) if the offer sets a deadline by which it must be accepted, the offer is irrevocable until that date. In contrast, the UCC provides all offers are revocable unless promised otherwise by a merchant in writing. To this issue, the civil code is not clear as to whether Art. 1693 is an exception for Art. 1690 \& 1691 . Under the CISG, a revocable offer becomes irrevocable when the offeree mails its acceptance or if the offeree relies on the offer. This gives rise to a potential claim for full contractual damages rather than simply a reliance interest or other quasi-contractual or equitable remedy. But, under the civil code (Art. 1693), an offer is irrevocable as soon as it reaches for the address of the offeree. In relation to this issue, Sylvette argued that, unlike the ${ }^{7}$ Ibid, see e.g. UCC, part 2, 2-201. 
UPICC, both the PECL (Art. 1:303(3)) \& the CISG as a rule followed the theory of reception, but in case of non-performance the transmission theory prevails (Guillemard, 2000/2001).

\subsubsection{Notice for Offer and Acceptance}

Unlike CISG, both UPICC (Art. 1.10) \& PECL (Art. 1.303) state that the notice becomes effective only when it reaches the person to whom it is intended. This cognizance of the principle that the party who sends the notice has to take the risk of loss. But, even the CISG (Art. 27) provides that a delay or failure of the notice to be received by the other party does not affect the right of the notifying party. The civil code \& UCC lack clarity on this issue.

\subsubsection{Means of Communication}

While the CISG (Art. 20(1)) \& UPICC (Art. 2.8(1)) make distinction between non-instantaneous and other means of communication, the civil code (Art. 1681) \& PECL (Art. 1:304) make an implied distinction between written and other means of communication. The UCC includes all types of communication and as per §2-211 \& ff. it governs electronic contract in which the civil code failed to do so.

\subsubsection{Parole Evidence Rule}

US courts in applying the UCC will generally exclude testimony that contradict the specific terms of the parties which has been specified under the written agreement which is known as parole evidence rule. ${ }^{8}$ And, under UCC, oral evidence cannot be used if it contradicts with the terms of a written contract. However, New York Federal Court in Calavidia v. Olivieri footwear Ltd, case specifically states that "the CISG, unlike the American contract law, [does] not include parole evidence rule, and allows all relevant information in to evidence even if it contradicted with the written agreement (Zara Law Offices, 2015).

In contrast to UCC, the CISG, UPICC and PECL do not exclude the use of parole evidence. Regarding the admissibility of evidences, the Ethiopian civil code resembles to UCC parole evidence rule. Accordingly, a written instruments shall be conclusive evidence, as between those who signed it, of the agreement therein contained and of the date it bears. ${ }^{9}$ Neither proof by witnesses nor any presumption against such statements should be admissible. ${ }^{10}$

\subsubsection{Validity of a Contract}

As stated above, whereas the civil code, UPICC \& PECL govern the validity of a contract such as defects in the formation of a contract, the CISG (Art. 5) and UCC (\$1-103) do not regulate the validity of a contract. But, exceptionally, §2-302 of UCC provides the issue of unconscionable contract.

Besides, whereas the CISG and the civil code required the definiteness of terms and price (but, in relation to price Art. 55 of the CISG \& Art. 2271 of the CC may fill the gap), §2-204(3) of UCC provides that a valid contract can be created even if the offer fails to state certain items such as quantity or price. With respect to error, the UPICC (art 3.5.1) seems to refer, at least partially, to an objective test, as they measure the importance of error from the perspective of a "reasonable person" whereas the PECL considers the matter from the points of the parties. ${ }^{11}$ The civil code (Art. 1997) seems to follow the position of PECL.

\subsubsection{Time and Place of Formation of a Contract}

In regard to the place of formation of the contract, the CISG, UPICC as well as PECL do not foresee a rule to such effect. The civil code (Art. 1692) regulates the time and place of conclusion of a contract between absent parties. $^{12}$

\subsection{Interpretation a Contract}

The provisions of the governing law and/or term of a contact should be interpreted in line with good faith, usag${ }^{8}$ UCC, §2-202.

${ }^{9}$ Civil Code, Art. 2005(1).

${ }^{10}$ Ibid, Art. 2006(2).

${ }^{11}$ Ibid.

${ }^{12}$ Ibid, Art. 1692 provides “A contract made between absent parties shall deemed to be made at the place where and time when the acceptance was sent to the offer or, and a contract made by telephone shall be deemed to be made at the place where the party was called”. But, party autonomy is intact. 
es and practice, to achieve uniformity and so on (see CISG (Art 7 \& 9), UPICC (Art 1.6, 1.7 \& 1.9) PECL (Art. $1 ; 106 \& 1 ; 102$, UCC (\$1-103)). Similarly, the civil code recognized the same type of interpretation in many of its provisions (see e.g. Art. 1713, Art 1731 and ff, 2291, 2292).

Unlike the CISG and civil code which are silent, both UPICC (Art 1.9(2)) \& PECL (Art 1:105) stated that usages do not bind the parties to a contract when it would be unreasonable to do so taking into account the nature of the transaction.

The UPICC (Art. 1.7), PECL (Art. 1:20) and civil code (Art. 1713), all imposed up on the parties a duty to act in good faith throughout the life of contract, including the negotiation process i.e. formation, validity, interpretation and performance. But, the CISG expressly limits good faith for the purpose of interpretation of the convention as such.

The UPCC and PECL (Art. 5:107) determine the fate of the contract that is drawn up in two or more languages that "the contract drawn in two or more different language and none of which is stated authoritative, and in case of disparity between the versions, a preference for the interpretation would be given to the version in which the contract was originally drawn up”. However the Ethiopian civil code and CISG are silent in this regard.

\subsection{Performance and Remedies of Non-Performance of Contract}

\subsubsection{Performance of a Contract}

Whereas the UPICC (Art 6.1.5) \& PECL (Art 7:1) states that the creditor can reject performance of the contract prior to the due date only if it has a legitimate interest, CISG (Art. 52(1)) does not mention a legitimate interest as a requirement. The civil code lacks clarity on this issue.

Unlike the civil code \& CISG which are silent, the UPICC (Art 6.12 \& 6.13) and PECL (Art 7:109) expressly regulated the issue of appropriation of performance in case of many obligations on a party. But, the gap in the civil code can be filled by the cumulative reading of Art. 1676(1) and Art. 1752 \& ff. The gap in the CISG too filled by UPICC \& PECL.

Obligation of the Contracting Parties

1) Obligation of the Seller

a) Obligation to Deliver

The obligation of the seller to deliver the thing includes the delivery of the agreed amount as well as the thing at the agreed time and place.

The civil code (Art. 2279 and 2280), CISG (Art 31) \& UCC (\$2-308) provided that the place of delivery is the place chosen by parties or the seller's place of business or the seller's normal residence respectively. Where the sale relates to specific thing or fungible thing, the place of delivery is at the place where the thing situated or produced at the time of conclusion of a contract. However, under the UPICC (Art 6.1.6) \& PECL (Art 7:101), in the absence of specification by the contract, the place of performance is the creditor's place of business in case of monetary obligation or the debtor's place of business in case of non-monetary obligation i.e. in both cases, place of business at the time of the conclusion of a contract is taken into consideration. Unlike UPICC, under the PECL (Art 7:101(3)), if a party does not have a place of business, his/her habitual residence is to be treated as a place of business.

Under CISG (Art. 31(1)), in case of goods transported via carriage, the place where the goods loaded on the first carrier (independent carrier) is considered as a place of delivery. But, the civil code is silent on this issue.

The UCC (\$2-208) stated that documents of title may be delivered via customary banking channels. But, the civil code does not provides the ways of transfer of documents.

The CISG (Art. 33), UPICC (Art. 6.1.1), and PECL (Art. 7:102) stated that time of performance is the time fixed by the contract i.e. it may beat fixed date or with in fixed period of time; in other cases, reasonable time after conclusion of the contract. The UCC (\$2-309) used reasonable time in the absence of specification by contract. However, under the civil code (Art. 2276), in the absence of specification by the parties, the seller should deliver the thing as soon as the buyers requires him to do so.

b) Obligation to warranty of title, defects, and non-conformity

Warranty is a contractual promise by the seller regarding the quality, character, or suitability of the goods s/he has sold and it includes the obligation to warranty of dispossession (Art 2281, 2282 of CC, Art 41 of CISG, §2.312 of UCC), defect (Art 2287 \& 2295 of CC, Art. 2-314 \& ff. of UCC), and non-conformity (Art 2287 \& 2288 CC, Art. 35 of CISG, §2-106 of UCC). However, the UPICC \& PECL do not have detailed provision on this topic. Under the civil code, CISG \& UCC, there is an underlying obligation of any seller to provide goods 
that are fit for their usual purpose. Under the UCC (§2-314 \& ff.), it is an implied warranty imposed by the law and the seller may disclaim its warranty only if they mention that word specifically, and such disclaimer must be both written and conspicuous. However, under the civil code and CISG, there is no any formalistic rules about warranty disclaimers and a valid disclaimer of warranty requires an express agreement of both parties, but it does not have to be either written or conspicuous.

Unlike the UCC (\$2-315) which requires the seller to have knowledge of the buyer's use for the particular purpose, in the civil code (Art. 2289) \& CISG (Art. 35(2)) create liability for a seller if the goods are not "fit for the purpose for which goods of the same description would ordinarily be used" even if the seller never had knowledge of how the buyer would use the specific goods.

Under the civil code (Art. 2283(1), Art. 2284, Art. 2285(3) \& Art. 2286) there is exhaustive legal limits in which warranty is not effective. The CISG does not consist all those legal limits.

Unlike the civil code, the CISG (Art. 41 \& Art. 42) differentiate corporeal rights from incorporeal rights (intellectual property). And, in relation to the latter, the obligation of conformity requires that goods are "free from any right or claim of a third party based on industrial property or other intellectual property" under some conditions of intellectual property right in the country of the buyer or place of resale if contemplated.

c) Obligation to transfer ownership

It is the basic principle of property law that a person can transfer no greater right in property than he himself possesses. Thus, the obligation to transfer ownership includes the obligation to have a good title. ${ }^{13}$ Unlike the civil code \& UCC, under the CISG the requirements for an effective transfer of property is the question of (national) property law.

2) Obligations of the buyer

a) Payment of the price

In relation to payment of the price the important issue that should be addressed by the contract or law are the place of payment, time of payment and mode of payment. ${ }^{14}$

Whereas the UPICC (Art 6.1.7 and ff.), PECL (Art 7:107 \& 7:108) and UCC (§. 2-304) clearly stipulated the mode of payment, the civil code and CISG do not expressly provide the modes of payment. But, the gap in the civil code can be filled by the cumulative reading of Art. 1676(1) and Art. 1749 \& ff and by the foreign exchange regulations and directives in Ethiopia. ${ }^{15}$

If parties fail to regulate price, the civil code and the CISG determine the price in some instances by its gap filling provisions (Art. 2305 \& ff. of CC and Art. 52(2), Art 55 \& ff. of CISG). However, whereas the civil code takes into consideration the market price upon delivery, the CISG takes in to consideration the market price of things upon the conclusion of the contract. Besides, the civil code have more gap filling provisions and wider in scope than the CISG.

b) Obligation to take delivery

As per Art. 2312 of CC \& Art. 60 of CISG the obligation to take delivery includes buyer must undertake all acts which could reasonably be expected of him in order to enable the seller to make delivery. These acts include the obligation to go to the place of the business of the seller and physically receive the thing from the seller or to keep the buyer's store opened if delivery is to be made at the buyer's place. It also includes the duty to accept the thing when the place of delivery is at the residence of the buyer when the thing does not suffer from any defects. The buyer's failure to pay the price might be equated to failure to take delivery when payment of the price is a precondition for delivery. Under the UPICC \& PECL there is no detail rules on this issue.

c) The obligation of examination

As per Art. 38 CISG \& Art. 2291 of CC the buyer must examine the goods within a short period and the examination must be objectively suitable for disclosing recognizable defects. Under the CISG (Art. 38(3)), for goods sold in transit and in case of re-dispatch is foreseen, examination may take at final destination. Similarly, $\S 2-513(1)$ of UCC provides the buyer can examine the goods upon arrival. But, there is not provision under the civil code to regulate the goods sold in transit.

d) The obligation of specification

The civil code (Art. 2334 \& 2335) and CISG (Art. 65) provide that the buyer has the obligation tospecify the form, measurement or other features of the goods.If the buyer failed to do so, the seller will choose and give

\footnotetext{
${ }^{13}$ see, e.g. UCC. §2-403.

${ }^{14}$ see e.g. UCC $\$ 2-310$.

${ }^{15}$ e.g. see Directive No. FXD/25/2004 (2004) Amendment to Directive No. FXD/24/2004 Establishment and Operation of Foreign Currency Account for Non-Resident Ethiopians and Non-Resident Ethiopian Origin, 12th of July 2004.
} 
notice thereof for the buyer. However, under the civil code the buyer's failure to specify may leads to the choice of the seller binding, but under the CISG buyer's failure to choose may leads to avoidance of the contract. There is no counterpart provisions under UPICC \& PECL.

3) Common Obligations of the Seller and the Buyer

a) Obligation to pay expenses

Whereas the UPICC (Art. 6.1.11) \& PECL (Art. 7:12) require each party to bear the cost of their own duty of performance, the civil code (Art. 2314 \& ff.) expressly specifies the potential cost to be borne by each party.

b) Duty to preserve the goods

The duty to preserve the goods is provided by the civil code (Art 2320 \& ff.), CISG (Art 85 \& ff.), and PECL (Art 7:110). Accordingly, a party who is bound to preserve the goods has the option of selling them and s/he can retain the reasonable cost of preserving and selling the goods from the proceeds of the sale.

Unlike the civil code, the CISG (Art. 88) \& PECL (Art. 7:110) impose obligation on a party to notify the other party of his/her intention of selling. On the other hand, unlike the CISG \& PECL, the civil code (Art. 2322 cum Art. 1781) imposes obligation on a party to get court permission to sell even perishable goods and in principle, the thing should be sold in public auction.

Besides, unlike the civil code and CISG, the PECL distinguishes the obligation of the party in case of property not accepted (Art 7:110) and money not accepted (Art 7:111).

c) Transfer of risk

General principles of economic analysis of contract tells us that risk shall be borne by the person who is in a better position of avoiding the risk or shared when none of the parties is in a better position of avoiding the risk (Tesfaye \& Fetewi, 2009). Risk is different from liability because the question of risk arises if the seller is not liable for non-conformity. Risk is transfered upon delivery and it follows the principle whcih says res peri demino or risk perishes to the owner or risk follows to the ownership (Tesfaye \& Fetewi, 2009). It's also usually governed by relevant incoterms. ${ }^{16}$

Unlike the CISG \& civil code which lack clarity, the UCC as per §2-318 \& ff incorporates most incoterms which need update inline with the present day incoterms.

Whereas the civil code \& the CISG expressly state the condition of risk transer, there are no clear provision under the UPICC \& PECL. Accordingly, under the civil code and CISG, risk transfers from the seller to the buyer in the following cases: upon delivery (Art. 1758(1) \& 2324 CC, Art. 69 CISG), delay of buyer (Art. 2325 \& 1758(2) CC, Art. 69 CISG), handing over to carriage (Art. 2326 CC, Art 67 \& 68 CISG).

Under the CISG the risk passes as per the agreement; if not agreed as per Art. 69 at the moment of delivery, but 1) If the buyer refuses to take delivery, risk passes at that time; 2) If other place than place of business of the seller, risk passes when delivery is due and the buyer is aware of the fact that the goods are placed at his disposal at that place. But, there is no similar provisions in the civil code.

Art. 2326 CC \& Art. 67 CISG provide that in case of carriage of the goods and if no particular place is identified the risk transfers as soon as the goods loaded on first carrier (independent carrier). But, if there is identified particular place, risk transfers as soon as the carrier reaches at that place.

Unlike the civil code, Art. 68 CISG provides that in case of goods sold in transit, the risk transfers at the moment of conclusion of the contract. Besides, unlike the CISG, the civil code (Art. 2327 \& 2728) emphasizes the special consideration when there are provisions relating to expenses and the goods are shipped in common.

\subsubsection{Remedies of Non-Performance of a Contract}

Contracting parties assume obligation which emanates from their express agreement, from the incidental effects of the contract and from the gap filling provisions. When the contracting parties do not comply with these obligations, it can be said that there is non-performance of the contract. ${ }^{17}$

The CISG and UCC provide for the same remedies in the event of breach (Liu, 2003). Accordingly, aggrieved parties can cancel the contract, sue for performance, or collect damages, including consequential damages. Due to this reason most federal courts in USA utilizing UCC provisions to interpret the CISG provisions (Wiesner et al., 2015).

1) Forced performance

Under the CISG (Art. 28, 46, \& 62) the buyer can choose between damages and specific performance without

\footnotetext{
${ }^{16}$ e.g. Incoterms 2010, formulated by the international chamber of commerce, it is the present updated Incoterms.

${ }^{17}$ see e.g. UPICC, Art 7.1.1.
} 
any discretion left to the court. However, according to the UPICC (Art. 7.2.1) and PECL (Art. 9:101 and 9:102), specific performance is not a discretionary remedy and a court is required to order specific performance. The civil code seems to follow the later approach. ${ }^{18}$

Forced performance can be required when certain failures happen that is when there is failure to deliver, when there is non-conformity or defects, and non-payment. So, the buyer may not require forced performance if the non performance is owing to dispossession even though he has a particular interest.

Under the CISG whether the buyer can claim specific performance or not depends upon the domestic law of the forum (Art. 28) and it's subject to the condition of not having recourse to other remedies that are inconsistent with it (Art. 46(1)). If specific performance is available, it includes 1) requiring delivery of substitute goods when breach is fundamental or 2) requiring repair unless unreasonable (Art. 46(2) and (3). The same is true under the UPICC (Art. 7.2.2) and PECL (Art. 9:101).

Under the CISG (Art. 48), UPICC (Art. 7.1.4 \& 7.2.3) \& PECL (Art. 8:104) the seller has the right to cure (repair) under certain conditions that secure the buyer's interests. Such right of the seller is not provided in the civil code (Art. 2332). But, the seller will cure if the buyer required to do so.

Where the buyer fails to pay the price, the seller may demand payment unless the sale relates to a thing in respect of which a compensatory sale is imposed by custom (Art. 2333 of CC and PECL (Art. 9:101)). Compensatory sale is possible when the thing can be sold to other persons. Here, under the UPICC (Art. 7.2.1) there is no requirement of compensatory sale.

Unlike the civil code which limits itself for the seller right of requiring payment, under the CISG (Art. 62) the seller has the right to compel taking delivery in addition to payment.

Unlike the civil code, the UPICC (Art. 7.2.4) provides that there will be judicial penalty in case of a party failed to perform what he is ordered by the court.

2) Suspension (withholding performance)

A party may suspend the performance of his obligations, if after the conclusion of the contract, it becomes clear that the other party will not perform a substantial part of his/her obligations (Art. 71 CISG, Art. 7.1.3 UPICC \& Art. 9:201 PECL).

Anticipatory breach will exist if prior to the date for performance by one of the parties, it is clear that there will be a fundamental nonperformance by that party. ${ }^{19}$ The UPCC provides the two terms one is the remedy for the other. Under art, 7.3.4 of UCC it states that if there is anticipatory nonperformance, the creditor may demand assurance of due performance and mean while with hold his/her own performance.

The CISG included the two in a single provision i.e. a party may suspend the performance of his obligations if, after the conclusion of the contract, it becomes apparent that the other party will not perform a substantial part of his obligations as a result of: 1) serious deficiency in his ability to perform or in his credit-worthiness; or 2) his conduct in preparing to perform or in performing the contract. ${ }^{20}$ So, in both UPCC and CISG withholding of performance is one of the effects of anticipatory breaches.

However, PECL entertains the withholding of contracts and anticipatory non-performance in different manner. Where prior to the time for performance by a party, it is clear that there will be a fundamental non-performance by one party, the other party may terminate the contract. ${ }^{21}$ Here, withholding is not one of the effects of anticipatory non-performance. PECL provides about withholding of performance in a separate provision. A party who is to perform simultaneously with or after the other party, may withhold performance until the other has tendered performance or has performed ${ }^{22}$. The first party may withhold the whole performance or a part of it as may be reasonable in the circumstances. (2) A party may similarly withhold performance for as long as it is clear that there will be a non-performance by the other party when the other party's performance becomes due. ${ }^{23}$

However, unlike the above international commercial instruments, the Ethiopian civil code totally ignores the issue of withholding contract. It only addresses the term anticipatory breach, the effect of which may results cancelation of the contract. ${ }^{24}$ But, even if there is no clear provision under the civil code, we can infer such rights of the parties from the provisions of Art. 2278(2) and 2310 CC.

\footnotetext{
${ }^{18}$ See civil code, Arts. 1776, 2330 \& 2333.

${ }^{19}$ UPICC, Art. 7.3.3.

${ }^{20}$ CISG, Art. 71 (1 (a and b)).

${ }^{21}$ PECL, Art. 9:304.

${ }^{22}$ Ibid, Art, 9:201(1)

${ }^{23}$ Ibid, Art 9:201(2).

${ }^{24}$ Civil code, Art, 2353.
} 
3) Cancellation/avoidance/termination

Cancellation is the action by which contracting parties make an already formed contract ineffective for the response of non-performance. It is known as termination by CISG, UPICC, \& PECL. But, under the civil code \& UCC (§2:106) beyond the difference in terminology, there is a substantive difference between termination and cancellation i.e. termination does not have retrospective effect.

Under the civil code (Art. 1785 cum Art. 2336 \& 2347), there is a pre-condition of fundamental breach and taking in to consideration of good faith for the cancellation of a contact. Similarly, the requirement of fundamental breach is provided under CISG (Art. 25 \& Art. 49), UPICC (Art. 7.3.1), and PECL (Art. 9:301).

In the civil code, fundamental breach is required if the parties want to cancel the contract. But, parties can terminate the contract even in the absence of breach through agreement. ${ }^{25}$

The civil code (Art. 2354 \& ff.), UPICC (Art. 7.3.5 \& ff.), PECL (Art. 9:305 \& ff.) provide the effects of termination/cancellation of a contract. Unlike UPICC, PECL, and civil code, the CISG does not contain any rule on effects on the already transferred property (whether it automatically restituted or not).

Unlike the CISG, UPICC \& PECL, the civil code expressly lists broad grounds of cancellation and recognized two kinds of cancellation i.e. judicial \& unilateral. The court may cancel a contract if an application for that effect is instituted by a party and upon the fulfillment of good faith and fundamental breach. Accordingly, under the civil code, the buyer can cancel a contract if there is lapses of compulsory date for delivery (Art. 2337); seller not deliver in designated place (Art. 2340); whole ownership not transferred to the buyer (Art. 2341); dispossession (Art. 2342); partial delivery (Art. 2343); defects (Art. 2344). The seller can also cancel a contract if there is: non-payment of price (Art. 2348), default in taking delivery (Art. 2349), and failure to make specifications (Art. 2350). Besides, unlike the UPICC \& PECL which provide cancellation by seller \& buyer in a single provisions, the civil code and CISG expressly provide that cancellation by the buyer and the seller in separate provisions.

4) Price réduction

The PECL (Art. 9:401) \& CISG (Art. 50) deal with the right to reduce the price in case of performance not conforming to the contract and to give effect to the provision of cure by non performing party. CISG gives the buyer the ability to unilaterally declare a price reduction even before he has paid the price. Similar provisions to reduce the price are absent in the civil code \& UPICC. But, the general principle of "damage should equal to damages" may fill such gaps of the civil code (Art 1790 CC).

5) Damages

Whereas the UPICC (Art 7.4.2(1)) second sentence provides that the amount of damages should be reduced by any advantages which the breach brings for the aggrieved party, the civil code, CISG \& PECL do not expressly addressed the issue. However, the principle of full compensation embodied under the CISG; the principle of "damage should be equal to damages" under the civil code (Art. 1779); the official commentaries on Art 9:502 of PECL ${ }^{26}$ states that "the aggrieved party must reduced the compensation to the extent of his/her gains which can offset its loss can fills the gap” (Blasé \& Hottler, 2004).

Whereas Art 9:504 of PECL \& Art 7.4.7 of UPICC expressly state the amount of damages should be apportioned between the parties in accordance with the degree of causation by the respective parties, the civil code $\&$ CISG do not expressly govern the issue.

Unlike CISG, both PECL (Art 9:501(2)(a)(b) \& UPICC (Art 7.4.2(2) \& Art 7.4.3(1-3)) expressly stated "recoverable loss includes future loss that is reasonably likely to occur and such a loss may also take the form of loss of a chance, non-pecuniary loss and so on”. Art. 1790(2) of the civil code recognized the applicability of the provisions of extra-contractual liability which includes among other things this types of loss.

Unlike the CISG, the civil code (Art. 2364), PECL (Art 9:509) \& UPICC (Art 7.4.13) take into consideration reliance interest; punitive damages and penalty clause during the calculation of damages. UCC (§, 2-718) also recognizes liquidated damages. Under UCC, if parties determine exaggerated amount of damages may not be effective and be reduced. However, in the civil code, parties are at liberty to determine any amount of penalty as they want.

UCC allows a buyer to collect consequential damages for "injury to person or property proximately resulting from any breach of warranty". But, the CISG (Art. 5) expressly forbids these damages. The doctrine of "full compensation" (Art. 1790) may fill the gap in civil code.

\footnotetext{
${ }^{25}$ Civil code, Art 1819(1).

${ }^{26}$ For further information see http:// cisgw3.law. pace.edu/cisg/text/preclomp74.htmp\# cnpc, last visited on February 10/2016.
} 
Whereas the civil code \& CISG do not provide for the currency in which the damages are to be paid, Art 9:510 PECL provides that damages are to be measured by the currency in which most appropriately reflects the aggrieved party loss. Similarly, Art 7.4.12 UPICC states that damages are to be measured either in the currency in which the monetary obligation was expressed or in which the harm was suffered, whichever is more appropriate. The gap in the civil code can be filled by the cumulative reading of Art 1676(1) and Art 1749 \& ff, and by the foreign exchange regulation and directives in Ethiopia. ${ }^{27}$

6) Interest

CISG (Art. 78) deals with interest payments but makes no reference to the rate of interest. The civil code (Art 2361(2), UPICC (7.4.9) and PECL (Art. 9.508)) provides for rate of interest. To fill the gaps under the CISG, national law (or UPICC \& PECL) may apply. But, the question is which national law: lexcontractus or lexmonatae will apply? According to CISG Advisory Council Opinion 14: "In the absence of an agreement, the applicable rate of interest is the rate which the court at the creditor's place of business would grant in a similar contract of sale not governed by the CISG"28 (CISG, 2014).

\section{Summary, Conclusion and Recommendation}

\subsection{Summary and Conclusion}

From the comparisons, we can understand that the Ethiopian civil code governing sales of goods are incompatible with the aforementioned international convention and principles on the areas of scope of applicability, interpretation, formation of the contract, obligation of the parties, risk of loss, breach of contract and remedies.

In relation to scope of applicability, the CISG, UPICC \& PECL give the parties an opportunity to exclude some of its provisions. But, there is no counterpart provision under the civil code.

For the formation of a contract, a contract greater than $\$ 500$ should be in written by UCC, but it is left to the freedom of parties under the civil code, CISG, UPICC \& PECL. And, the requirement of meeting of minds during exchange of offer and acceptance is provided by the civil code, CISG, UPICC \& PECL. But, there is no such requirement under the UCC.

The provisions of the governing law and/or term of a contact should be interpreted in line with good faith, usages and practice, to achieve uniformity and so on. But, the CISG requires good faith to interpret the convention itself but not the contract.

In an international contract of sale of goods, one of the important issues to be addressed under the law is obligation of the parties. Accordingly, the seller has the obligation to deliver, give warranty, and transfer ownership. Similarly, the buyer has the obligation to pay the price, take delivery, examination, and specification. This obligation of the parties is well regulated under the civil code and CISG, but not under UPICC and PECL.

The risk of loss usually governed by relevant incoterms and the UCC incorporates some Incoterms. But, the civil code, CISG, UPICC, \& PECL failed to incorporate those Incoterms.

One remedy of breach of a contract is forced performance and it is given to the discretion of the aggrieved party under the CISG, but it is the duty of the court under the civil code, UPICC \& PECL.

Unlike the civil code, UPICC, and PECL, punitive and penalty clause does not provide under CISG. The UCC recognizes it via liquidated damages.

In case of partial performance, price reduction as an alternative remedy for non-performance is provided under the CISG \& PECL. But, the civil codes, UPICC \& UCC lack clarity on this issue.

The mode of payment is important to pay the price of a goods and the compensation awarded for non-performance or defective performance. And, it's provided by UPICC \& PECL, but the civil code and CISG fail to provide it.

The UCC allows for the buyer to collect consequential damages for "injury to person or property proximately resulting from any breach of warranty”. But, the civil codes, CISG, UPICC and PECL, lack clarity on this issue.

Therefore, from the comparison we can understand that one body of law is not a perfect body of law, and neither can it be, and to some extent they enable themselves to supplement each other and fit well with each other, rather than compete or claim to displace the other.

\subsection{Recommendation}

Based on the findings of this paper, the researcher would like to propose the following recommendations for

${ }^{27}$ For further information see Directive No. FXD/25/2004 (2004)_discussed above \& fully cited under supra note 24.
${ }^{28}$ For further information see www.cisg.law. pace.edu/cisg/CISG-AC... last visited on February 10/2016. 
different concerning organs.

To the revision committee of the civil code: to update the civil code in line with the international contracts and principles in general and in particular to:

- give the parties an opportunity to exclude some part of its provisions;

- regulate the place \& examination of delivery of transit on carrier;

- incorporate price reduction as alternative remedies for partial non-performance;

- incorporate the Incoterms 2010 and periodically update it in line with the new standards of terms, an option to be a member of international chamber of commerce;

- specify the place, time and mode document delivery;

- explicitly declare the validity and enforceability of electronic sale contracts.

To the drafting committee of Ethiopian private international law: to take in to consider all the above international contracts and principles especially to understand their similarity and incompatibility and then, to formulate a comprehensive law.

To the executive and legislative body: to approve the above international legal instruments especially the CISG and to give due attention before their signature and approval. For example to put reservations in some provisions that will jeopardize the interest of an Ethiopian trader.

To the contracting parties: to give due attention and properly understand each law before their choice of the forum and/or governing law. For example, they can choice multiple laws to regulate a contract via excluding part of the provisions of a given law say the CISG.

To the revision committee of CISG, UPICC, PECL and UCC: to update their respective laws and/or principles based on the finding of this paper.

\section{References}

Blasé, F., \& Höttler, P. (2004). Remarks on the Damages Provisions in the CISG, Principles of European Contract Law (PECL) and UNIDROIT Principles of International Commercial Contracts (UPICC).

Bonell, M. J. (2002). The UNIDROIT Principles of International Commercial Contracts and the Harmonization of International Sales Law. 339.

Bonell, M. J. et al. (1994). Towards a European Civil Code (p. 37). Martinus Nijhoff Publishers.

Civil Code of Ethiopia (1960). The Federal Negarit Gazeta Year, No. 2, Proclamation No. 165/1960.

Directive No. FXD/25/2004 (2004). Amendment to Directive No. FXD/24/2004 Establishment and Operation of Foreign Currency Account for Non-Resident Ethiopians and Non-Resident Ethiopian Origin, 12th of July.

FDRE Ministry of Justice and Justice and Legal System Research Institute (2004). Initial Draft to Provide for Federal Rules of Private International Law, Art. 73.

Fernando, R. (2015). CISG, UNIDROIT Principles and PECL Compared. https://www.linkedin.com/pulse/cisg-unidroit-principles-pecl-compared-rohan-fernando

Guillemard, S. (2000/2001). A Comparative Study on the UNIDROIT Principle and the PECL and Some Disposition of the CISG Applicable to the Formation of International Contracts from the Perspectives of Harmonization of Laws (pp. 83113). Kluwer Law International. www.cisg.law.pace.edu

Kebede, A., \& Kassim, S. (2009). Conflict of Law Teaching Materials. FDRE Ministry of Justice and legal System Research Institute. www.chilot.com

Liu, C. W. (2003). Remedies for Non-Performance, Perspective from CISG, UNIDROIT Principles \& PECL, Law School of Renmin University of China. http://cisgw3.law.pace.edu/network.html\#cp

Marell, L. S. (2016). How Does the CISG Differ from the UCC? http://marell-lawfirm.com/how-does-the-cisg-differ-from-the-ucc/

Principle of European Law (2002). http://www.trans-lex.org

Tesfaye, G., \& Fetewi, M. (2009). Law of Sales and Security Devices Teaching Materials (pp. 102-111). FDRE Ministry of Justice and Legal System Research Institute. www.chilot.com

U.N. Convention on Contracts for the International Sale of Goods, Apr. 11, 1980, S. Treaty Doc. No. 98-9 (1983). 1489 U.N.T.S. http://www.uncitral.org/pdf/english/clout/CISG-digest-2012e.pdf http://www.cisgac.com/default.php?sid=128

UNIDROIT Principles of International Commercial Contracts (2010). http://www.uncitral.org/uncitral/en/index.html

Uniform Commercial Code, Vol. 10 (2007). Uniform Commercial Code. 
http://onlinelibrary.wiley.com/doi/10.1111/j.1744-1714.1964.tb01260.x/abstract

Wiesner, R. M. et al. (2015). Understanding the CISG and Its Interrelation with the UCC. www.wdc-online.org/index.php/wdc-jo

WTO (2015). World Trade Organization, International Trade Statistics of 2015. https://www.wto.org/english/res_e/statis_e/its2015_e/its2015_e.pdf

Zara Law Offices (2015). World Trade Organization, UCC versus CISG—Which One Should a Foreign. www.zaralawny.com/english/articles/

\section{Acronyms}

CC: Civil code of Ethiopia

CISG: The United Nations Convention on Contracts for International Sale of Goods

UPICC: The UNIDROIT Principle of International Commercial Contracts 2010

PECL: The Principles of European Contract Law

UCC: The Uniform Commercial Code

Submit or recommend next manuscript to SCIRP and we will provide best service for you:

Accepting pre-submission inquiries through Email, Facebook, Linkedin, Twitter, etc A wide selection of journals (inclusive of 9 subjects, more than 200 journals)

Providing a 24-hour high-quality service

User-friendly online submission system

Fair and swift peer-review system

Efficient typesetting and proofreading procedure

Display of the result of downloads and visits, as well as the number of cited articles

Maximum dissemination of your research work

Submit your manuscript at: http://papersubmission.scirp.org/ 